\title{
Chimeric antigen receptor for adoptive immunotherapy of cancer: latest research and future prospects
}

\author{
Huan Shi ${ }^{1}$, Meili Sun ${ }^{2}$, Lin Liu ${ }^{1 *}$ and Zhehai Wang ${ }^{1 *}$
}

\begin{abstract}
Chimeric antigen receptors (CARs) are recombinant receptors that combine the specificity of an antigen-specific antibody with the T-cell's activating functions. Initial clinical trials of genetically engineered CAR T cells have significantly raised the profile of T cell therapy, and great efforts have been made to improve this approach. In this review, we provide a structural overview of the development of CAR technology and highlight areas that require further refinement. We also discuss critical issues related to CAR therapy, including the optimization of CAR T cells, the route of administration, CAR toxicity and the blocking of inhibitory molecules.
\end{abstract}

Keywords: Adoptive transfer, Chimeric antigen receptor, Gene transfer, T cells

\section{Introduction}

Adoptive cellular therapy (ACT) has received much attention as a realistic technique for cancer treatment [1-3]. Tumor-reactive $\mathrm{T}$ cells can be isolated from tumorinfiltrating lymphocytes (TILs) and then expanded in vitro before re-infusion back into cancer patients [4]. The adoptive transfer of TILs yields a durable regression of melanoma tumors $[5,6]$. However, the process by which tumor-reactive TILs are isolated and expanded is technically difficult, labor-intensive and time-consuming. Moreover, another limitation in the more widespread application of TIL therapy is the difficulty in identifying antigen-specific $\mathrm{T}$ cells in other cancer types.

To overcome these obstacles and to broaden the applications of ACT, gene-therapeutic approaches for the redirection of T-cells to defined tumor-associated antigens (TAAs) have been developed [7]. One sophisticated strategy involves the engineering of autologous T-cells with a chimeric antigen receptor (CAR) [8], which is composed of a specific antigen-binding moiety that is derived from the variable regions of a monoclonal antibody $(\mathrm{mAb})$ and linked through a hinge and a transmembrane (TM) motif to a cytoplasmic lymphocyte-signaling moiety $[9,10]$.

\footnotetext{
*Correspondence: linliu1028@gmail.com; wzhai8778@yahoo.com 1 Department of Oncology, Shandong Cancer Hospital and Institute, No. 440 Jiyan Road, Jinan, Shandong 250117, P.R. China

Full list of author information is available at the end of the article
}

The CARs endow T cells antigen-specific recognition, activation and proliferation in an MHC-independent manner. Current clinical trials using engineered CAR T cell therapy demonstrate clinical responses in both hematological malignancies and solid tumors [2,11]. Here, we will provide an overview of the recent development of the CAR technology and discuss the challenges and future prospects for this pioneering approach.

\section{CAR binding domain}

The classic CAR consists of an extracellular antigenrecognition domain attached to an extracellular spacer/ hinge domain, a TM region that anchors the receptor to the cell surface and a signaling endodomain. A scFv derived from the variable heavy chain $(\mathrm{VH})$ and variable light chain (VL) regions of an antigen-specific mAb linked by a flexible linker is commonly utilized as the extracellular TAA-binding domain in most CARs (Figure 1A). The scFv retains the same specificity and a similar affinity as the full antibody from which it was derived [12]. Moreover, the small molecular size of scFvs facilitates both the genetic manipulation and expression of the CAR. Furthermore, it determines the CAR antigen specificity and binds the target protein in an MHC-independent manner. To date, the scFvs of CARs are most often derived from mouse mAbs. Human anti-mouse antibody (HAMA) responses can occur within days and can block antigen recognition 


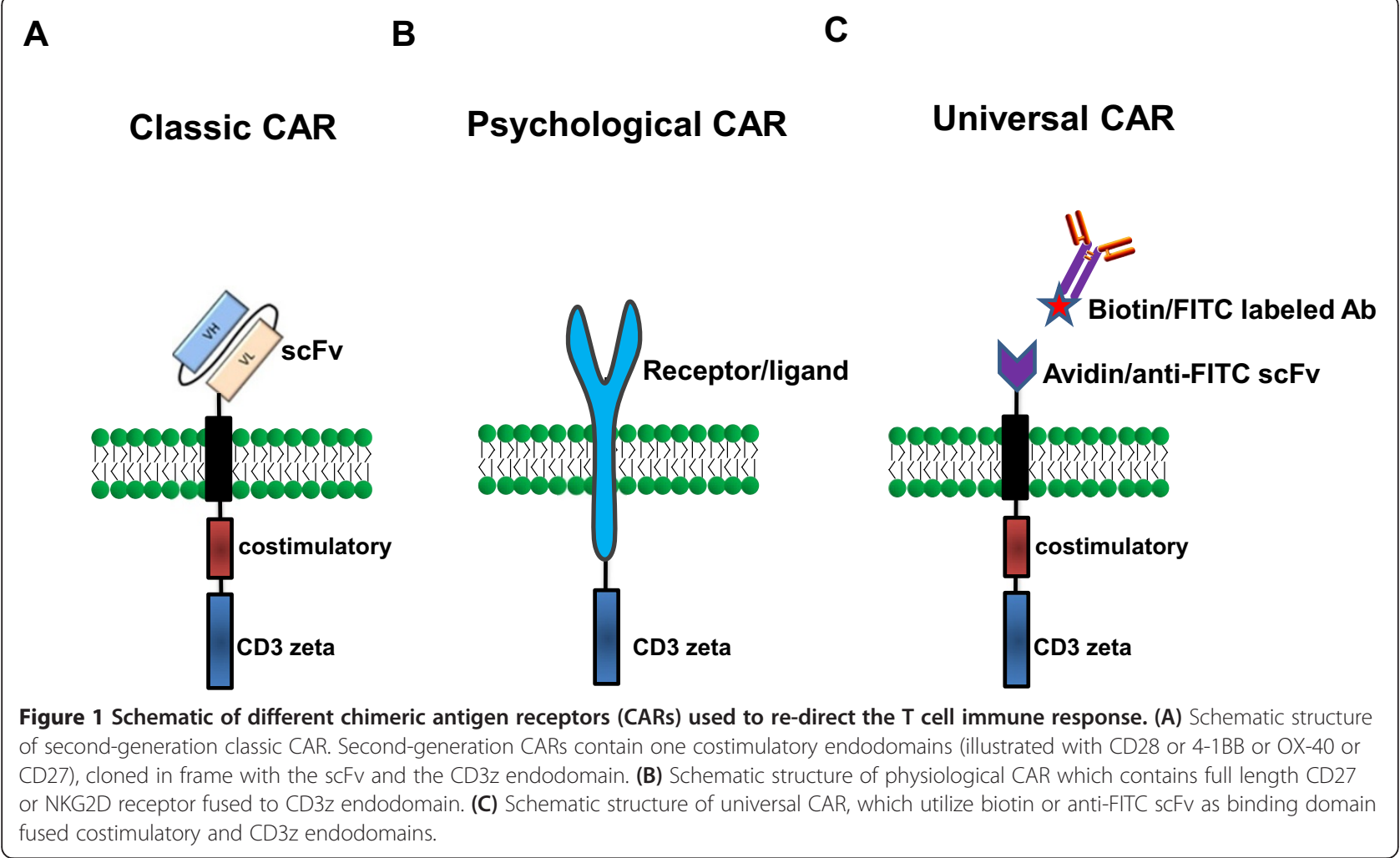

by CARs. Therefore, the use of humanized [13] or fully human $\mathrm{scFv}$ [14] may be preferable to mouse scFv. In addition, the affinity of scFv must be considered in the design of CARs. The affinity of the scFv selected for designing a CAR also should be considered. Hudecek et al. [15] showed that increasing the affinity of a CAR enhances its T-cell effector function and recognition of tumors. However, the development of higher affinity CARs with greater anti-tumor activity could theoretically increase the risk of on-target toxicity and mandates careful safety studies in a relevant model.

The extracellular antigen-recognition domain of CARs can also be a ligand for a receptor that is expressed on tumor cells [11]. Non scFv-based ligand-binding domains have been utilized in a CAR format (Figure 1B). For example, the CD27 receptor [16], the heregulin molecule (a ligand for Her3 and Her4 receptors) [17], interleukin (IL)13 mutein [18], vascular endothelial growth factor (antiVEGFR2) [19], and the NKG2D receptor [20-22], have been used successfully for engineered T-cell therapy, resulting in tumor regression in vivo. Recently, a novel chimeric NKp30 CAR targeting the B7-H6 (NKp30 ligand) expressing tumor was developed [23].

To expand the applications for T cell-based immunotherapy in cancer, Tamada et al. [24] and Urbanska et al. [25] constructed similar "universal" CARs (uCAR) that utilize anti-fluorescein isothiocyanate (FITC) $\mathrm{scFv}$ and avidin in either a monomeric (mcAv) or dimeric (dcAv) form as binding domains fused to T-cell signaling domains, respectively (Figure $1 \mathrm{C}$ ). These uCAR $\mathrm{T}$ cells recognize various cancer types when bound to FITClabeled or biotinylated antigen-specific mAbs or scFvs, resulting in efficient target lysis, T-cell proliferation, and cytokine production. More recently, Kudo et al. [26] constructed a novel uCAR containing the high-affinity CD16 (FCGR3A) V158 variant, CD8 $\alpha$ hinge and transmembrane domains, along with signaling domains. CD16V-based uCAR $\mathrm{T}$ cells have bound humanized antibodies with higher affinity and engagement of the CD16V-uCAR provoked $\mathrm{T}$ cell activation, exocytosis of the lytic granules and sustained proliferation. Further, the co-administration of CD16V uCAR T cells with immunotherapeutic antibodies exerted considerable antitumor activity in vivo. Importantly, the treatment of immunocompromised mice using the novel uCAR T cells plus the labeled mAbs currently in clinical use exhibited potent antitumor activity. The need for many different immune receptor genes to cover all cancers limits the feasibility of ACT, and the use of uCARs may address this issue.

\section{CAR targeting}

Most antigens targeted by CAR-T cells are simply 'tumorassociated' and not 'tumor-specific'. The potential for "on-target, off-organ" toxicity is a serious concern in CAR 
T-cell therapy. Thus, the judicious selection of TAAs is the first step and is critical to the success of CAR-based ACT. CD19 is the widely and successfully utilized target of CAR-modified T cells [27-29], being universally expressed by acute lymphoblastic leukemia, the most common malignancy of children, whereas its expression on non-tumor tissues is restricted to B-cells and their progenitors, but not hematopoietic stem cells. The toxicity of targeting this antigen using anti-CD19 CAR-modified T cells is limited to $\mathrm{B}$ cell aplasia and the consequent effects on humoral immunity, which is considered to be a tolerable side-effect of this therapy [11]. In contrast, one colon cancer patient treated with Her2/neu CAR-T cells died 5 days after the adoptive transfer; this patient died of what appears to have been a cytokine storm and respiratory failure triggered by the recognition of the low levels of antigens on lung epithelial cells [30]. These studies suggest that ideal TAAs are required by the tumor cell for survival and should show restricted expression to the tumor cell surface and otherwise non-vital tissues.

The effect of antigen density for CAR therapy is not yet well defined. It appears that CAR $T$ cells typically target highly expressed antigens, while low antigenexpressing tumor cells are resistant to CAR $\mathrm{T}$ cell therapy $[31,32]$. This resistance could be a limitation in their activity against tumors expressing low antigen levels. The intensity of antigen expression on target cells, however, can be increased by the administration of epigenetic modulators [32]. On the other hand, lesser sensitivity may become an advantage when the avoidance of low-level antigen expression on normal cells is desirable.

\section{CAR signaling}

CARs are grouped into three generations of increasing costimulatory activity (Figure 1A). The first-generation CARs contain a single signaling unit that is most commonly derived from the CD3z chain or FcRg subunits [33]. However, first-generation CARs have limited clinical activity for the treatment of lymphoma, neuroblastoma, and ovarian and renal cancer [34-37] because the activation of the CAR-modified $\mathrm{T}$ cells induces only transient cell division and suboptimal cytokine production, and these functions fail to produce prolonged $\mathrm{T}$ cell expansion and sustained antitumor effects [38].

The therapeutic success of adoptive therapy with CAR $\mathrm{T}$ cells depends on the appropriate costimulation of $\mathrm{CD} 3 \mathrm{z}$ to induce full T-cell activation [39]. These CARs contain costimulatory signaling domains derived from the $\mathrm{T}$ cell costimulatory molecules, such as CD28, which is the molecule most commonly selected by CARs [29,40-42]. However, other costimulatory molecules, such as 4-1BB (CD137), OX40 (CD134), ICOS and CD27, also play important roles in regulating $\mathrm{T}$-cell proliferation, survival, and antitumor functions $[10,41,43]$. Notably, Porter et al.
[44] described a heavily pretreated patient with chronic lymphocytic leukemia (CLL) who had a complete remission. This remission was associated with the tumor lysis syndrome following the transfer of second-generation CD19 CAR-T cells coupled with 4-1BB and CD3z signaling domains.

A special second-generation CAR developed recently separates the $\mathrm{T}$ cell signaling domains into two different CARs, one of which contains the costimulatory signaling domains, such as CD28 or 4-1BB, while the other CAR, with a different specificity, contains only the CD3z signaling domain. This strategy reproduces the physiological signals' 1 and 2 checkpoints of $\mathrm{T}$ cell activation. Wilkie et al. [45] have tested this principle by coexpressing Her2- and MUC1-specific CARs that signal using $\mathrm{CD} 3 \mathrm{z}$ and $\mathrm{CD} 28$, respectively. They found that "dual-targeted" T cells kill Her2 + tumor cells efficiently and proliferate in a manner that requires the co-expression of MUC1 and Her2 by tumor cells in vitro. Recently, Kloss et al. [46] presented a similar strategy and co-transduced $\mathrm{T}$ cells to express CARs targeting the prostate tumor antigens PSMA and PSCA. They showed that co-transduced T cells destroy tumors that express both antigens but do not affect tumors that express either antigen alone. Hence, the potential for "on-target" toxicity should be reduced. These findings further pave the way for testing the safety of this strategy in clinical trials.

Furthermore, combining the signaling from multiple signaling molecules, such as CD3, CD28, and CD137 (or CD134) to form a 3rd generation CAR has also been tested $[47,48]$. In a clinical setting, Till et al. have reported that CARs containing three activation motifs have potent anti-tumor efficacy [49].

\section{CAR hinge and transmembrane}

In addition to signaling domains, previous studies [50,51] highlight the requirement of a spacer/hinge domain inserted between the $\mathrm{scFv}$ binding and transmembrane (TM) domain in CD3z-signaling CARs for its stable expression on the surface of $\mathrm{T}$ cells. A spacer or flexible hinge region domain mediates CAR flexibility and appears to be important for ensuring the suitable positioning of the binding domain during $\mathrm{scFv}$-antigen interactions [51,52]. In addition, the TM domains have significant effects on the cell surface expression of CARs and may also influence CAR function. For example, Pulè et al. [53] showed that CARs containing the CD28 TM domain result in the highest expression, while the CAR transduction with the OX40 and CD3z TM domains have intermediate and the lowest expressions, respectively. Zhang et al. [23] also showed that CD28 TM-containing chimeric NKp30 CARs often show greater surface expression than do CARs with CD3z TM, perhaps because the CD28 TM-containing CARs tend to predominantly form 
homodimers independent of the TCR-CD3 complex, whereas the CD3z TM-containing CARs can form heterodimers of CAR with the endogenous CD3z chain that may be limited by the TCR-CD3 complex expression. Greater expression of CD28 TM-containing CARs was shown to correlate with better functional activity.

Currently, various TM regions have been employed in CAR, including CD3z [18], FceRI [54], CD4 [55], CD7 [56], CD8 [10,47], CD28 [10,47], OX40 [57] and H2-Kb [58]. However, there is evidence supporting the notion that the intracellular domains, rather than the TM domains, mediate stable cell surface expression [59]. Additional comparative studies of different cytoplasmic and TM domains are required.

\section{Generation of CAR modified T cells}

Both lentiviruses and retroviruses have been widely used as gene transfer vectors, and they compose the vector system that is currently used in the majority of clinical gene therapy trials for cancer [60] (Figure 2). However, the lentiviral vectors have become more widely used and are advantageous because they mediate the efficient transduction of cells, can be used with both dividing and nondividing cells, result in long-term, stable transgene expression and appear to be less prone to gene silencing [60]. Nonviral gene transfer technologies have been explored for gene therapy. Dr. Cooper's group $[61,62]$ reported a new nonviral approach for the electrotransfer of DNA plasmids using the Sleeping Beauty (SB) transposon/transposase system into primary human $\mathrm{T}$ cells, which resulted in efficient and stable CD19-specific CAR gene expression.

An alternative non-viral approach that does not rely on transgene integration, which uses RNA electroporation, results in transient CAR expression, precluding effective T-cell persistence beyond a week [63] (Figure 2).
The use of transient CAR T cells, which require multiple injections to provide meaningful tumor responses, may reduce the destruction of normal tissues or prevent T-cell accumulations to levels that increase the risk of cytokine storms [64]. More recently, mRNA CAR T cells have mediated antitumor activity in patients with advanced solid tumors [65]. Thus, these results support the development of mRNA CAR-based strategies for cancer therapy.

\section{Optimization of CAR T cells}

It is now clear that the adoptive transfer of the lessdifferentiated naive $\left(\mathrm{T}_{\mathrm{N}}\right)$ or central memory $\left(\mathrm{T}_{\mathrm{CM}}\right) \mathrm{T}$ cell subsets is associated with superior $\mathrm{T}$ cell engraftment, persistence, and antitumor activity, thus correlating highly with the objective clinical responses [66]. These subsets can be enriched using cell surface molecules such as CD62L before the CAR introduction; these cells have been shown to persist to a greater extent in vivo than the more differentiated $T$ cells $[67,68]$. A recently identified stem cell-like population of T cells [69] with strong engraftment potential in peripheral blood may be more effective for ACT and is worth exploring for CARredirected targeting in vivo. Moreover, when common $\gamma$ chain cytokines such as IL-7, IL-15, and IL-21 are added to the $\mathrm{T}$ cell cultures, they shift the final $\mathrm{T}$ cell phenotype towards that of a less-differentiated $\mathrm{T}$ cell type [70,71]. Furthermore, the chemokine system plays a major role in driving $\mathrm{T}$ cell migration. Therefore, the expression of specific chemokine receptors that can aid in the precise trafficking of $\mathrm{T}$ cells to tumors have been explored, including the co-expression of CXCR2 and CCR2b on CAR-T cells [72-74].

\section{Route of administration of CAR T cells}

Although systemic (intravenous, IV) injection is favored in clinical applications because of its ease of administration,

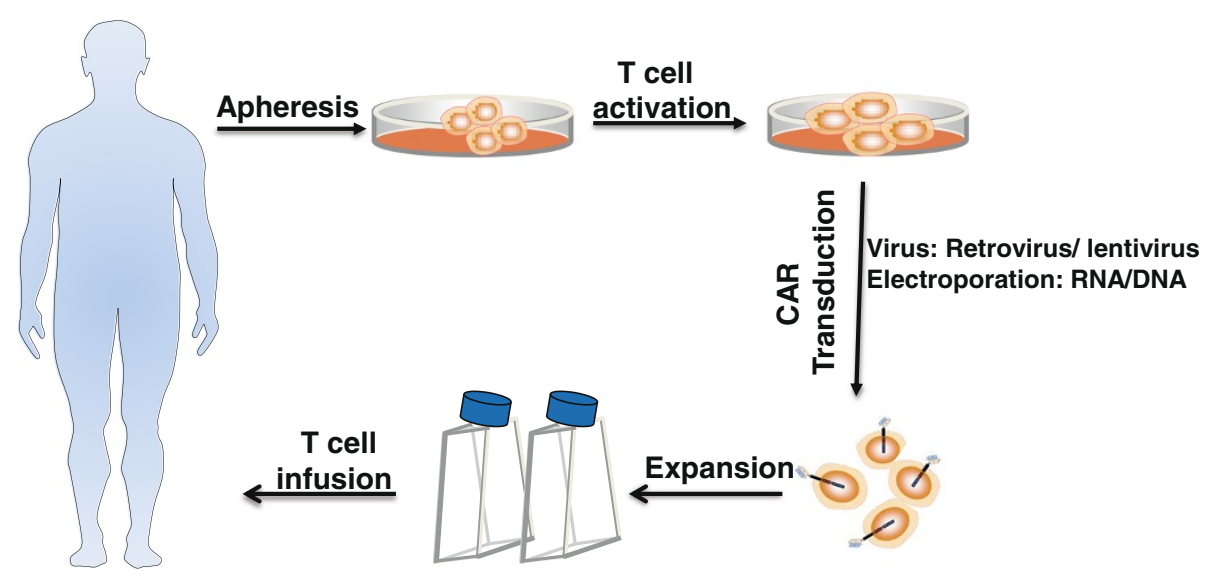

Figure 2 Schema for adoptive cellular therapy with genetically modified CAR T cells. T cells can be isolated from patient blood by apheresis, and genetically modified to express a transgene encoding a tumor-specific CAR. The genetically modified T cells are then expanded in vitro using several approaches before infusion into the patient. 
several preclinical studies $[47,75,76]$ suggest that the regional (intratumoral, IT or intraperitoneal, IP) administration of $\mathrm{T}$ cells may provide optimal therapeutic effects, which may be in part due to increased T-cell trafficking to the tumor.

Indeed, Dr. Maher's group [76] showed that CAR $\mathrm{T}$ cells remain at the site of inoculation with minimal systemic absorption when delivered via IP or IT routes. In contrast, after IV administration, CAR T cells initially reach the lungs and then are redistributed to the spleen, liver, and lymph nodes. These findings may help to explain the development of rapid lung toxicity [30] and grades 2-4 liver toxicity [36] in Her2-specific CAR and CAIX-specific CAR T cell therapy trials. More recently, Dr. Maher's group [77] showed that ErbB CAR T cells elicit antitumor activity in mice in the absence of detectable clinical or histologic toxicity when administered in moderate doses by the IV or IP routes. However, when large numbers of these cells are administered using the IP route, cytokine release syndrome results. In contrast, when delivered using the IT route, T-cells remain at the site of injection for several days, where they promote tumor regression but never elicit cytokine release syndrome. These findings raise the possibility that ErbBtargeted $\mathrm{T}$ cells may prove useful in the treatment of human malignancy provided that the dosing and route of administration are optimized carefully. To test this possibility, Dr. Maher's group [78] recently designed a protocol for the phase I clinical testing of the intratumoral injection of CAR $\mathrm{T}$ cells in locally advanced or recurrent head and neck squamous cell carcinomas (Clinicaltrials.gov number: NCT01818323). Intratumoral injection may provide a safe and potentially effective management strategy for CAR therapy.

In addition, RNA CAR-electroporated $\mathrm{T}$ cells may be particularly suitable for regional administration, due to the transient nature of the CAR expression on the T cells [64]. Furthermore, clinical studies have shown the feasibility and safety of both the intratumoral and intraperitoneal injection of T cells $[79,80]$.

Overall, a local route of administration of the engineered T cells may provide the optimal therapeutic effect and decrease the potential for the "on-target, off-organ" toxicity discussed below.

\section{CAR toxicity}

The immune-mediated recognition of targeted antigens in normal tissues is referred to as "on-target, off tumor" toxicity. "On-target" toxicity was first reported for the CAIX CAR [36], which was used to treat patients with metastatic renal cell cancer and consisted of limiting the liver enzyme elevations that were most likely caused by the CAR $\mathrm{T}$ cells that recognized the CAIX antigen expressed at low levels on the bile duct epithelial cells. The elimination of the normal B-cell compartment in the patients treated with CD19-specific CAR $\mathrm{T}$ cells represents an expected on-target toxicity that can be managed by administering intravenous immunoglobulin $[27,81]$.

In addition, tumor lysis syndrome (TLS) and cytokine release syndrome (CRS) were also reported in patients treated with CD19 CAR T cells [27,44,81]. TLS is a group of metabolic abnormalities that results from the rapid release of intracellular metabolites from lysed malignant cells and is most frequently associated with hematological malignancies after the initiation of cytotoxic treatment [82]. However, TLS may be delayed, occurring one month or more after the CD19 CAR T cell infusion [44]. TLS has been managed successfully by standard supportive therapy, including allopurinol, hydration, alkalinization, and rasburicase [83]. CRS that is induced by CAR $\mathrm{T}$ cell therapy was recently reviewed [84]. CRS is a disorder characterized by nausea, headache, tachycardia, hypotension, rash, and shortness of breath caused by the release of cytokines from the immune cells. CRS is also frequently observed in the clinical trials that treat hematological malignancies with CAR T cells. Severe CRS is described as a cytokine storm, which can be fatal [30]. CRS usually occurs 6-20 days after the infusion of CAR T cells, although it may occur in a very short time in some patients and may be related to various CAR structures, underlying diseases and the patients' genetic polymorphisms. The current management of CRS includes corticosteroids, cytokine antagonists and supportive therapy [84]. In addition, CRS-related mortality should be reduced by designing safer CARs, following a strict dose-escalation scheme, intensively monitoring the inflammatory cytokines and taking timely and effective measures, including the administration of various antagonists of cytokines under the current situation [84].

In addition to these toxicities, anaphylaxis has been reported in patients infused with CAR-T cells. Maus et al. [85] reported the safety observed in four patients treated with mRNA electroporated murine anti-human mesothelin CAR T cells. One subject developed anaphylaxis and cardiac arrest within minutes of completing the third infusion, most likely because it induced an IgE antibody specific for the murine-based antibody sequences present in the CAR-modified T-cell product. These results indicate that the potential immunogenicity of CARs derived from murine antibodies may be a safety issue for mRNA CARs, especially when administered using an intermittent dosing schedule.

\section{Blocking inhibitory molecules}

Despite encouraging results in clinical trials, the existence of a number of different immunosuppressive pathways 
can limit the full potential of CAR $\mathrm{T}$ cell therapies. The interaction of inhibitory molecules on activated T-cells and their ligands on tumor cells compromises T-cell function. This includes the increased expression of inhibitory immune receptors such as T-cell membrane protein-3 (TIM-3), cytotoxic $\mathrm{T}$ lymphocyte-associated antigen 4 (CTLA-4), and/or programmed death-1 (PD-1) on T cells following T-cell activation, which can limit the duration and strength of the adaptive immune response [86].

Promising clinical results infusing mAbs that block the interaction between PD-1 and PD-L1 (or PDL2) in patients with solid tumors have been reported $[87,88]$. Thus, blocking this pathway may further enhance the antitumor activity of the gene-modified $\mathrm{T}$ cells. Indeed, John et al. [89] first showed that the expression of the PD-1 receptor was significantly increased on Her2 CAR $\mathrm{T}$ cells following its coculture with PD-L1+ Her-2+ expressing tumor targets. They further demonstrated that the administration of an anti-PD-1 antibody can significantly enhance the therapeutic efficacy of CAR T-cell therapy in vivo. On September 4, 2014, U.S. Food and Drug Administration (FDA) approved anti-PD-1 antibody pembrolizumab for the treatment of patients with unresectable or metastatic melanoma. These results are encouraging for moving towards testing this combined approach in a clinical setting.

\section{Conclusions and future directions}

In conclusion, our review discussed the development of CAR technology and highlighted some key issues for avoiding the severe adverse events of CAR T cells-based therapy. The judicious selection of candidate TAAs is essential for improving efficacy and safety. Factors that require further consideration include the CAR design, the affinity of the scFv, the density of target molecules, disease burden, the route of administration of CAR T cells and the tumor microenvironment.

CAR-based ACT has emerged as a promising immunotherapeutic strategy and already has shown impressive success, particularly for patients with hematological malignancies. Currently, investigators are extending this strategy to solid tumors [90]. Genetic engineering strategies can meet some of the requirements for an effective CARbased therapy [2], which includes enabling T cells/NK cells to respond more powerfully against tumor cells and facilitating trafficking to tumors and persistence for long periods. To maximize therapeutic safety, introducing a controllable suicide gene such as an inducible caspase-9 (iCasp9) as a safety switch may increase the safety of cellular therapies and expand their clinical applications. With further modifications in the laboratory and an increased number of clinical trials to test this strategy, engineered CAR-based ACT for cancer may provide significant improvements in cancer immunotherapy.

\section{Abbreviations}

CARs: Chimeric antigen receptors; ACT: Adoptive cellular therapy;

TILs: Tumor-infiltrating lymphocytes; TM: Transmembrane; mAb: Monoclonal Antibody; TAAs: Tumor-associated antigens; HAMA: Human anti-mouse antibody; TLS: Tumor lysis syndrome; CRS: Cytokine release syndrome; TIM-3: T-cell membrane protein-3; CTLA-4: Cytotoxic T lymphocyte-associated antigen 4; PD-1: Programmed death-1.

\section{Competing interests}

The authors declare that they have no competing interests.

\section{Authors' contributions}

HS, MS, LL and ZW drafted and finalized the manuscript. All authors read and approved the final manuscript.

\section{Acknowledgments}

This work was supported in part by grants from the National Science Foundation for Young Scientists of China (Grant No. 81402195) and Young Science and Technology Star Program of Jinan (Grant No. 20120134).

\section{Author details}

'Department of Oncology, Shandong Cancer Hospital and Institute, No. 440 Jiyan Road, Jinan, Shandong 250117, P.R. China. ${ }^{2}$ Department of Oncology, Jinan Central Hospital affiliated to Shandong University, No. 105, Jie Fang Road, Jinan, Shandong 250013, P.R. China.

Received: 12 June 2014 Accepted: 17 September 2014

Published: 21 September 2014

\section{References}

1. Rosenberg SA: Cell transfer immunotherapy for metastatic solid cancerwhat clinicians need to know. Nat Rev Clin Oncol 2011, 8:577-585.

2. Shi H, Liu L, Wang Z: Improving the efficacy and safety of engineered T cell therapy for cancer. Cancer Lett 2013, 328:191-197.

3. June CH: Adoptive T cell therapy for cancer in the clinic. J Clin Invest 2007, 117:1466-1476.

4. Dudley ME, Rosenberg SA: Adoptive-cell-transfer therapy for the treatment of patients with cancer. Nat Rev Cancer 2003, 3:666-675.

5. Dudley ME, Wunderlich JR, Robbins PF, Yang JC, Hwu P, Schwartzentruber DJ, Topalian SL, Sherry R, Restifo NP, Hubicki AM: Cancer regression and autoimmunity in patients after clonal repopulation with antitumor lymphocytes. Science 2002, 298:850-854.

6. Rosenberg SA, Dudley ME: Adoptive cell therapy for the treatment of patients with metastatic melanoma. Curr Opin Immunol 2009, 21:233-240.

7. Anurathapan U, Leen AM, Brenner MK, Vera JF: Engineered T cells for cancer treatment. Cytotherapy 2014, 16:713-33.

8. Eshhar Z: The T-body approach: redirecting T cells with antibody specificity. Handb Exp Pharmacol 2008, 181:329-342.

9. Sadelain $M$, Rivière I, Brentjens R: Targeting tumours with genetically enhanced T lymphocytes. Nat Rev Cancer 2003, 3:35-45.

10. Song D-G, Ye Q, Poussin M, Harms GM, Figini M, Powell DJ: CD27 costimulation augments the survival and antitumor activity of redirected human $\mathrm{T}$ cells in vivo. Blood 2012, 119:696-706.

11. Liu L, Sun M, Wang Z: Adoptive T-cell therapy of B-cell malignancies: conventional and physiological chimeric antigen receptors. Cancer Lett 2012, 316:1-5.

12. Bird RE, Hardman KD, Jacobson JW, Johnson S, Kaufman BM, Lee S-M, Lee T, Pope SH, Riordan GS, Whitlow M: Single-chain antigen-binding proteins. Science 1988, 242:423-426.

13. Westwood JA, Smyth MJ, Teng MW, Moeller M, Trapani JA, Scott AM, Smyth FE, Cartwright GA, Power BE, Hönemann D: Adoptive transfer of $T$ cells modified with a humanized chimeric receptor gene inhibits growth of Lewis-Y-expressing tumors in mice. Proc Natl Acad Sci U S A 2005, 102:19051-19056.

14. Turatti F, Figini M, Alberti P, Willemsen RA, Canevari S, Mezzanzanica D: Highly efficient redirected anti-tumor activity of human lymphocytes transduced with a completely human chimeric immune receptor. J Gene Med 2005, 7:158-170.

15. Hudecek M, Lupo-Stanghellini M-T, Kosasih PL, Sommermeyer D, Jensen MC, Rader C, Riddell SR: Receptor affinity and extracellular domain modifications 
affect tumor recognition by ROR1-specific chimeric antigen receptor T cells. Clin Cancer Res 2013, 19:3153-3164.

16. Shaffer DR, Savoldo B, Yi Z, Chow KK, Kakarla S, Spencer DM, Dotti G, Wu M-F, Liu H, Kenney S: T cells redirected against CD70 for the immunotherapy of CD70-positive malignancies. Blood 2011, 117:4304-4314.

17. Muniappan A, Banapour B, Lebkowski J, Talib S: Ligand-mediated cytolysis of tumor cells: use of heregulin-zeta chimeras to redirect cytotoxic $T$ lymphocytes. Cancer Gene Ther 2000, 7:128.

18. Kahlon KS, Brown C, Cooper $\sqcup$, Raubitschek A, Forman SJ, Jensen MC: Specific recognition and killing of glioblastoma multiforme by interleukin 13-zetakine redirected cytolytic T cells. Cancer Res 2004, 64:9160-9166.

19. Niederman TM, Ghogawala Z, Carter BS, Tompkins HS, Russell MM, Mulligan RC: Antitumor activity of cytotoxic T lymphocytes engineered to target vascular endothelial growth factor receptors. Proc Natl Acad Sci 2002, 99:7009-7014

20. Zhang T, Barber A, Sentman CL: Generation of antitumor responses by genetic modification of primary human T cells with a chimeric NKG2D receptor. Cancer Res 2006, 66:5927-5933.

21. Song D-G, Ye Q, Santoro S, Fang C, Best A, Powell DJ Jr: Chimeric NKG2D CAR-expressing T cell-mediated attack of human ovarian cancer is enhanced by histone deacetylase inhibition. Hum Gene Ther 2013, 24:295-305.

22. Lehner M, Götz G, Proff J, Schaft N, Dörrie J, Full F, Ensser A, Muller YA, Cerwenka A, Abken H: Redirecting T cells to Ewing's sarcoma family of tumors by a chimeric NKG2D receptor expressed by lentiviral transduction or mRNA transfection. PLoS One 2012, 7:e31210

23. Zhang T, Wu M-R, Sentman CL: An NKp30-based chimeric antigen receptor promotes $\mathrm{T}$ cell effector functions and antitumor efficacy in vivo. J Immunol 2012, 189:2290-2299.

24. Tamada K, Geng D, Sakoda Y, Bansal N, Srivastava R, Li Z, Davila E: Redirecting gene-modified T cells toward various cancer types using tagged antibodies. Clin Cancer Res 2012, 18:6436-6445

25. Urbanska K, Lanitis E, Poussin M, Lynn RC, Gavin BP, Kelderman S, Yu J, Scholler N, Powell DJ: A universal strategy for adoptive immunotherapy of cancer through use of a novel T-cell antigen receptor. Cancer Res 2012, 72:1844-1852

26. Kudo K, Imai C, Lorenzini P, Kamiya T, Kono K, Davidoff AM, Chng WJ, Campana D: T lymphocytes expressing a CD16 signaling receptor exert antibody-dependent cancer cell killing. Cancer Res 2014, 74:93-103.

27. Grupp SA, Kalos M, Barrett D, Aplenc R, Porter DL, Rheingold SR, Teachey DT, Chew A, Hauck B, Wright JF: Chimeric antigen receptor-modified T cells for acute lymphoid leukemia. N Engl J Med 2013, 368:1509-1518.

28. Brentjens RJ, Davila ML, Riviere I, Park J, Wang X, Cowell LG, Bartido S, Stefanski J, Taylor C, Olszewska M: CD19-targeted T cells rapidly induce molecular remissions in adults with chemotherapy-refractory acute lymphoblastic leukemia. Sci Transl Med 2013, 5:177ra138-177ra138.

29. Savoldo B, Ramos CA, Liu E, Mims MP, Keating MJ, Carrum G, Kamble RT, Bollard CM, Gee AP, Mei Z: CD28 costimulation improves expansion and persistence of chimeric antigen receptor-modified T cells in lymphoma patients. J Clin Invest 2011, 121:1822.

30. Morgan RA, Yang JC, Kitano M, Dudley ME, Laurencot CM, Rosenberg SA Case report of a serious adverse event following the administration of $T$ cells transduced with a chimeric antigen receptor recognizing ERBB2. Mol Ther 2010, 18:843-851.

31. James SE, Greenberg PD, Jensen MC, Lin Y, Wang J, Till BG, Raubitschek AA, Forman SJ, Press OW: Antigen sensitivity of CD22-specific chimeric TCR is modulated by target epitope distance from the cell membrane. J Immunol 2008, 180:7028-7038.

32. Anurathapan U, Chan RC, Hindi HF, Mucharla R, Bajgain P, Hayes BC, Fisher WE, Heslop HE, Rooney CM, Brenner MK: Kinetics of tumor destruction by chimeric antigen receptor-modified T cells. Mol Ther 2014, 22:623-33.

33. Eshhar Z, Waks T, Gross G, Schindler DG: Specific activation and targeting of cytotoxic lymphocytes through chimeric single chains consisting of antibody-binding domains and the gamma or zeta subunits of the immunoglobulin and T-cell receptors. Proc Natl Acad Sci 1993, 90:720-724.

34. Kershaw MH, Westwood JA, Parker LL, Wang G, Eshhar Z, Mavroukakis SA, White DE, Wunderlich JR, Canevari S, Rogers-Freezer L: A phase I study on adoptive immunotherapy using gene-modified T cells for ovarian cancer. Clin Cancer Res 2006, 12:6106-6115.
35. Park JR, DiGiusto DL, Slovak M, Wright C, Naranjo A, Wagner J, Meechoovet HB, Bautista C, Chang W-C, Ostberg JR: Adoptive transfer of chimeric antigen receptor re-directed cytolytic T lymphocyte clones in patients with neuroblastoma. Mol Ther 2007, 15:825-833.

36. Lamers CH, Sleijfer S, Vulto AG, Kruit WH, Kliffen M, Debets R, Gratama JW, Stoter G, Oosterwijk E: Treatment of metastatic renal cell carcinoma with autologous T-lymphocytes genetically retargeted against carbonic anhydrase IX: first clinical experience. J Clin Oncol 2006, 24:e20-e22.

37. Till BG, Jensen MC, Wang J, Chen EY, Wood BL, Greisman HA, Qian X, James SE, Raubitschek A, Forman SJ: Adoptive immunotherapy for indolent non-Hodgkin lymphoma and mantle cell lymphoma using genetically modified autologous CD20-specific T cells. Blood 2008, 112:2261-2271.

38. Brocker $\mathrm{T}$, Karjalainen $\mathrm{K}$ : Signals through $\mathrm{T}$ cell receptor-zeta chain alone are insufficient to prime resting T lymphocytes. J Exp Med 1995, 181:1653-1659.

39. Bridgeman J S, Hawkins R E, Hombach A A, Abken H, Gilham D E: Building better chimeric antigen receptors for adoptive T cell therapy. Curr Gene Ther 2010, 10:77-90.

40. Kowolik CM, Topp MS, Gonzalez S, Pfeiffer T, Olivares S, Gonzalez N, Smith DD, Forman SJ, Jensen MC, Cooper $: \mathrm{CD} 28$ costimulation provided through a CD19-specific chimeric antigen receptor enhances in vivo persistence and antitumor efficacy of adoptively transferred T cells. Cancer Res 2006, 66:10995-11004.

41. Finney HM, Akbar AN, Lawson AD: Activation of resting human primary $T$ cells with chimeric receptors: costimulation from $\mathrm{CD} 28$, inducible costimulator, CD134, and CD137 in series with signals from the TCR? chain. J Immunol 2004, 172:104-113.

42. Loskog A, Giandomenico V, Rossig C, Pule M, Dotti G, Brenner M: Addition of the CD28 signaling domain to chimeric T-cell receptors enhances chimeric T-cell resistance to T regulatory cells. Leukemia 2006, 20:1819-1828.

43. Shen C-J, Yang Y-X, Han EQ, Cao N, Wang Y-F, Wang Y, Zhao Y-Y, Zhao L-M, Cui J, Gupta P: Chimeric antigen receptor containing ICOS signaling domain mediates specific and efficient antitumor effect of $T$ cells against EGFRvill expressing glioma. J Hematol Oncol 2013, 6:33.

44. Porter DL, Levine BL, Kalos M, Bagg A, June CH: Chimeric antigen receptor-modified T cells in chronic lymphoid leukemia. N Engl J Med 2011, 365:725-733.

45. Wilkie S, van Schalkwyk MC, Hobbs S, Davies DM, van der Stegen SJ, Pereira ACP, Burbridge SE, Box C, Eccles SA, Maher J: Dual targeting of ErbB2 and MUC1 in breast cancer using chimeric antigen receptors engineered to provide complementary signaling. J Clin Immunol 2012, 32:1059-1070.

46. Kloss CC, Condomines M, Cartellieri M, Bachmann M, Sadelain M: Combinatorial antigen recognition with balanced signaling promotes selective tumor eradication by engineered T cells. Nat Biotechnol 2013, 31:71-75.

47. Carpenito C, Milone MC, Hassan R, Simonet JC, Lakhal M, Suhoski MM, Varela-Rohena A, Haines KM, Heitjan DF, Albelda SM: Control of large, established tumor xenografts with genetically retargeted human T cells containing CD28 and CD137 domains. Proc Natl Acad Sci 2009, 106:3360-3365.

48. Hombach AA, Abken $\mathrm{H}$ : Costimulation by chimeric antigen receptors revisited the $\mathrm{T}$ cell antitumor response benefits from combined CD28-OX40 signalling. Int J Cancer 2011, 129:2935-2944.

49. Till BG, Jensen MC, Wang J, Qian X, Gopal AK, Maloney DG, Lindgren CG, Lin Y, Pagel JM, Budde LE: CD20-specific adoptive immunotherapy for lymphoma using a chimeric antigen receptor with both CD28 and 4-1BB domains: pilot clinical trial results. Blood 2012, 119:3940-3950.

50. Moritz D, Groner B: A spacer region between the single chain antibody-and the CD3 zeta-chain domain of chimeric T cell receptor components is required for efficient ligand binding and signaling activity. Gene Ther 1995, 2:539-546.

51. Guest RD, Hawkins RE, Kirillova N, Cheadle EJ, Arnold J, O'Neill A, Irlam J, Chester KA, Kemshead JT, Shaw DM: The role of extracellular spacer regions in the optimal design of chimeric immune receptors: evaluation of four different scFvs and antigens. J Immunother 2005, 28:203-211.

52. Hombach A, Hombach A, Abken H: Adoptive immunotherapy with genetically engineered $T$ cells: modification of the $\lg \mathrm{G} 1 \mathrm{Fc}$ 'spacer'domain in the extracellular moiety of chimeric antigen receptors avoids 'off-target'activation and unintended initiation of an innate immune response. Gene Ther 2010, 17:1206-1213.

53. Pulè MA, Straathof KC, Dotti G, Heslop HE, Rooney CM, Brenner MK: A chimeric $T$ cell antigen receptor that augments cytokine release and supports clonal expansion of primary human T cells. Mol Ther 2005, 12:933-941.

54. Schambach A, Swaney WP, van der Loo JC: Design and production of retro-and lentiviral vectors for gene expression in hematopoietic cells. Methods Mol Biol 2009, 506:191-205. 
55. Jensen M, Tan G, Forman S, Wu AM, Raubitschek A: CD20 is a molecular target for scFvFc: zeta receptor redirected T cells: implications for cellular immunotherapy of CD20+ malignancy. Biol Blood Marrow Transplant 1998, 4:75-83

56. Patel S, Moskalenko M, Smith D, Maske B, Finer M, McArthur J: Impact of chimeric immune receptor extracellular protein domains on $\mathrm{T}$ cell function. Gene Ther 1999, 6:412.

57. Hombach AA, Heiders J, Foppe M, Chmielewski M, Abken H: OX40 costimulation by a chimeric antigen receptor abrogates CD28 and IL-2 induced IL-10 secretion by redirected CD4+ T cells. Oncoimmunology 2012, 1:458-466.

58. Geiger TL, Nguyen P, Leitenberg D, Flavell RA: Integrated src kinase and costimulatory activity enhances signal transduction through single-chain chimeric receptors in T lymphocytes. Blood 2001, 98:2364-2371.

59. Heuser C, Hombach A, Lösch C, Manista K, Abken H: T-cell activation by recombinant immunoreceptors: impact of the intracellular signalling domain on the stability of receptor expression and antigen-specific activation of grafted T cells. Gene Ther 2003, 10:1408-1419.

60. Sinn P, Sauter S, McCray P: Gene therapy progress and prospects: development of improved lentiviral and retroviral vectors-design, biosafety, and production. Gene Ther 2005, 12:1089-1098.

61. Singh H, Manuri PR, Olivares S, Dara N, Dawson MJ, Huls H, Hackett PB, Kohn DB, Shpall EJ, Champlin RE: Redirecting specificity of T-cell populations for CD19 using the sleeping beauty system. Cancer Res 2008, 68:2961-2971.

62. Maiti SN, Huls H, Singh H, Dawson M, Figliola M, Olivares S, Rao P, Zhao YJ, Multani A, Yang G: Sleeping beauty system to redirect T-cell specificity for human applications. J Immunother 2013, 36:112-123.

63. Zhao Y, Zheng Z, Cohen CJ, Gattinoni L, Palmer DC, Restifo NP, Rosenberg SA, Morgan RA: High-efficiency transfection of primary human and mouse $T$ lymphocytes using RNA electroporation. Mol Ther 2006, 13:151-159.

64. Zhao Y, Moon E, Carpenito C, Paulos CM, Liu X, Brennan AL, Chew A, Carroll RG, Scholler J, Levine BL: Multiple injections of electroporated autologous $T$ cells expressing a chimeric antigen receptor mediate regression of human disseminated tumor. Cancer Res 2010, 70:9053-9061.

65. Beatty GL, Haas AR, Maus MV, Torigian DA, Soulen MC, Plesa G, Chew A, Zhao Y, Levine BL, Albelda SM: Mesothelin-specific chimeric antigen receptor mRNA-engineered T cells induce antitumor activity in solid malignancies. Cancer Immunology Research 2014, 2:112-20.

66. Klebanoff CA, Gattinoni L, Restifo NP: Sorting through subsets: which T-cell populations mediate highly effective adoptive immunotherapy? J Immunother 2012, 35:651-660.

67. Berger C, Jensen MC, Lansdorp PM, Gough M, Elliott C, Riddell SR: Adoptive transfer of effector CD8+ T cells derived from central memory cells establishes persistent T cell memory in primates. J Clin Invest 2008, 118:294-305.

68. Hinrichs CS, Borman ZA, Cassard L, Gattinoni L, Spolski R, Yu Z, Sanchez-Perez L, Muranski P, Kern SJ, Logun C: Adoptively transferred effector cells derived from naive rather than central memory CD8+ T cells mediate superior antitumor immunity. Proc Natl Acad Sci 2009, 106:17469-17474.

69. Gattinoni L, Lugli E, Ji Y, Pos Z, Paulos CM, Quigley MF, Almeida JR, Gostick E, Yu Z, Carpenito C: A human memory T cell subset with stem cell-like properties. Nat Med 2011, 17:1290-1297.

70. Kaneko S, Mastaglio S, Bondanza A, Ponzoni M, Sanvito F, Aldrighetti L, Radrizzani M, La Seta-Catamancio S, Provasi E, Mondino A: IL-7 and IL-15 allow the generation of suicide gene-modified alloreactive self-renewing central memory human T lymphocytes. Blood 2009, 113:1006-1015.

71. Pouw N, Treffers-Westerlaken E, Kraan J, Wittink F, ten Hagen T, Verweij J Debets R: Combination of IL-21 and IL-15 enhances tumour-specific cytotoxicity and cytokine production of TCR-transduced primary T cells. Cancer Immunol Immunother 2010, 59:921-931.

72. Kershaw MH, Wang G, Westwood JA, Pachynski RK, Tiffany HL, Marincola FM, Wang E, Young HA, Murphy PM, Hwu P: Redirecting migration of T cells to chemokine secreted from tumors by genetic modification with CXCR2. Hum Gene Ther 2002, 13:1971-1980.

73. Craddock JA, Lu A, Bear A, Pule M, Brenner MK, Rooney CM, Foster AE: Enhanced tumor trafficking of GD2 chimeric antigen receptor T cells by expression of the chemokine receptor CCR2b. J Immunother 2010, 33:780.

74. Moon EK, Carpenito C, Sun J, Wang L-CS, Kapoor V, Predina J, Powell DJ, Riley $\mathrm{J}$, June $\mathrm{CH}$, Albelda SM: Expression of a functional CCR2 receptor enhances tumor localization and tumor eradication by retargeted human T cells expressing a mesothelin-specific chimeric antibody receptor. Clin Cancer Res 2011, 17:4719-4730.

75. Song D-G, Ye Q, Carpenito C, Poussin M, Wang L-P, Ji C, Figini M, June CH, Coukos G, Powell DJ: In vivo persistence, tumor localization, and antitumor activity of CAR-engineered T cells is enhanced by costimulatory signaling through CD137 (4-1BB). Cancer Res 2011, 71:4617-4627.

76. Parente-Pereira AC, Burnet J, Ellison D, Foster J, Davies DM, van der Stegen S, Burbridge S, Chiapero-Stanke L, Wilkie S, Mather S: Trafficking of CAR-engineered human T cells following regional or systemic adoptive transfer in SCID beige mice. J Clin Immunol 2011, 31:710-718.

77. van der Stegen SJ, Davies DM, Wilkie S, Foster J, Sosabowski JK, Burnet J, Whilding LM, Petrovic RM, Ghaem-Maghami S, Mather S: Preclinical in vivo modeling of cytokine release syndrome induced by ErbB-retargeted human T cells: identifying a window of therapeutic opportunity? J Immunol 2013, 191:4589-4598.

78. van Schalkwyk MC, Papa SE, Jeannon J-P, Urbano TG, Spicer JF, Maher J: Design of a phase I clinical trial to evaluate intratumoral delivery of ErbB-targeted chimeric antigen receptor T-cells in locally advanced or recurrent head and neck cancer. Human Gene Therapy Clinical Development 2013, 24:134-142.

79. Canevari S, Stoter G, Arienti F, Bolis G, Colnaghi MI, Di Re EM, Eggermont AM, Goey SH, Gratama JW, Lamers CH: Regression of advanced ovarian carcinoma by Intraperitoneal treatment with autologous TLymphocytes retargeted by a bispecific monoclonal antibody. J Natl Cancer Inst 1995, 87:1463-1469.

80. Duval L, Schmidt H, Kaltoft K, Fode K, Jensen JJ, Sorensen SM, Nishimura MI, von der Maase $\mathrm{H}$ : Adoptive transfer of allogeneic cytotoxic T lymphocytes equipped with a HLA-A2 restricted MART-1 T-cell receptor: a phase I trial in metastatic melanoma. Clin Cancer Res 2006, 12:1229-1236.

81. Kalos M, Levine BL, Porter DL, Katz S, Grupp SA, Bagg A, June CH: T cells with chimeric antigen receptors have potent antitumor effects and can establish memory in patients with advanced leukemia. Sci Trans/ Med 2011, 3:95ra73-95ra73.

82. Choi KA, Lee JE, Kim Y-G, Kim DJ, Kim K, Ko YH, Oh HY, Kim WS, Huh W: Efficacy of continuous venovenous hemofiltration with chemotherapy in patients with Burkitt lymphoma and leukemia at high risk of tumor lysis syndrome. Ann Hematol 2009, 88:639-645.

83. Cairo MS, Coiffier B, Reiter A, Younes A: Recommendations for the evaluation of risk and prophylaxis of tumour lysis syndrome (TLS) in adults and children with malignant diseases: an expert TLS panel consensus. Br J Haematol 2010, 149:578-586.

84. $\mathrm{Xu} \mathrm{X-J,} \mathrm{Tang} \mathrm{Y-M:} \mathrm{Cytokine} \mathrm{release} \mathrm{syndrome} \mathrm{in} \mathrm{cancer} \mathrm{immunotherapy}$ with chimeric antigen receptor engineered T cells. Cancer Lett 2014, 343:172-178.

85. Maus MV, Haas AR, Beatty GL, Albelda SM, Levine BL, Liu X, Zhao Y, Kalos M, June $\mathrm{CH}$ : T cells expressing chimeric antigen receptors Can cause anaphylaxis in humans. Cancer Immunology Research 2013, 1:26-31.

86. Pardoll DM: The blockade of immune checkpoints in cancer immunotherapy. Nat Rev Cancer 2012, 12:252-264.

87. Brahmer JR, Tykodi SS, Chow LQ, Hwu W-J, Topalian SL, Hwu P, Drake CG, Camacho LH, Kauh J, Odunsi K: Safety and activity of anti-PD-L1 antibody in patients with advanced cancer. N Engl J Med 2012, 366:2455-2465.

88. Topalian SL, Hodi FS, Brahmer JR, Gettinger SN, Smith DC, McDermott DF, Powderly JD, Carvajal RD, Sosman JA, Atkins MB: Safety, activity, and immune correlates of anti-PD-1 antibody in cancer. N Engl J Med 2012, 366:2443-2454.

89. John LB, Devaud C, Duong CP, Yong CS, Beavis PA, Haynes NM, Chow MT, Smyth MJ, Kershaw MH, Darcy PK: Anti-PD-1 antibody therapy potently enhances the eradication of established tumors by gene-modified T cells. Clin Cancer Res 2013, 19:5636-5646.

90. Rossig C: Extending the chimeric receptor-based T-cell targeting strategy to solid tumors. Oncoimmunology 2013, 2:e26091.

doi:10.1186/1476-4598-13-219

Cite this article as: Shi et al:: Chimeric antigen receptor for adoptive immunotherapy of cancer: latest research and future prospects. Molecular Cancer 2014 13:219. 